\title{
Spectral Depth Analysis of some Segments of the Bida Basin, Nigeria, using Aeromagnetic Data ${ }^{* 1}$ TSEPAV, MT; ${ }^{2}$ MALLAM, A
}

${ }^{I}$ Department of Physics, Ibrahim Badamasi Babangida University, Lapai, Nigeria

${ }^{2}$ Department of Physics, University of Abuja, Abuja, Nigeria

\begin{abstract}
Spectral depth analysis was carried out on ten (10) of the 2009 total magnetic field intensity data sheets covering some segments of the Bida basin, to determine the depth to magnetic basement within the basin. The data was obtained from the Nigerian Geological Survey Agency and used to produce a composite map of the study area which is situated within latitude $8^{0} 00^{\prime} \mathrm{N}-10^{\circ} 00^{\prime} \mathrm{N}$ and longitude $4^{0} 30^{\prime} \mathrm{E}-7^{\circ} 00^{\prime} \mathrm{E}$. Sixteen (16) overlapping blocks were generated from the ten sheets and Spectral depth analysis was performed on each of the blocks. The results delineated two prominent magnetic zones of shallow and deeper depths with the depth to the shallow magnetic sources $\left(\mathrm{h}_{1}\right)$ ranging from $0.254 \mathrm{~km}$ on Block 9 to $1.719 \mathrm{~km}$ on Block 2, having an average depth value of $0.968 \mathrm{~km}$. The depth to the deeper magnetic bodies, $\mathrm{h}_{2}$, on the other hand, varies between $1.830 \mathrm{~km}$ on Block 10 and $4.615 \mathrm{~km}$ on Block 15, with an average value of $3.063 \mathrm{~km}$. The shallower magnetic sources were attributed to near surface magnetic sources which could be laterite, ironstones or ferruginous sandstones that intruded into the sedimentary basin close to the surface. The places with deeper magnetic sources were ascribed to intrusions of the magnetic basement into the basin at deeper depths, lateral discontinuities in the basement and other features differing in magnetic susceptibilities such as dykes, faults, fractures, horsts and grabens within the study area. Based on these results, the Kainji (1), Fashe (2), Mokwa (4), Egbako (5), Baro (7), Patigi/Baro (14) and Baro/Gulu (15) spectral blocks with sedimentary thickness values above 3.0km show the greatest potential for hydrocarbon accumulation.
\end{abstract}

DOI: https://dx.doi.org/10.4314/jasem.v21i7.19

Copyright@2017 Tsepav and Mallam. This is an open access article distributed under the Creative Commons Attribution NonCommercial License (CC-BY-NC), which permits unrestricted use, distribution, and reproduction in any medium, provided the original work is properly cited.

Received 15 October 2017, received in revised form 19 September 2017, accepted 16 December 2017.

Keywords: Spectral Analysis, Depth to Magnetic Sources, Aeromagnetic data.

The Earth conceals a lot of natural resources that when harnessed, could be of economic and scientific importance. Most economic minerals, oil, gas, and groundwater lie concealed beneath the earth surface and the presence and magnitude of these resources can be ascertained by geophysical investigations of the subsurface geologic structures in the area. Advances in Earth sciences and technology have made it easier to view the Earth's subsurface clearer without necessarily piercing though it. This is done by studying the behaviour and characteristics of the properties associated with the Earth's interior, using geophysical tools. A wide range of geophysical methods exist and for each, there is an operative physical property to which the method is sensitive. The type of physical property to which a method responds clearly determines its range of application. Several geophysical works have been carried out in the basin using magnetic, electrical, gravity, seismic and other geophysical methods. For instance, Ofor $e t$ al. (2014) carried out a study of Pategi and Egbako areas of the lower Bida basin and revealed two prominent layers; with average values of $0.59 \mathrm{~km}$ and $3.1 \mathrm{~km}$ respectively. Megwara, and Udensi (2014) also carried out structural analysis using aeromagnetic data over parts of southern Bida basin and the surrounding basement rocks and found the depth to be within the range of $0.01 \mathrm{~km}$ to $0.51 \mathrm{~km}$ with an average value of $0.128 \mathrm{~km}$. Ojo and Ajakaiye (1989) delineated the presence of a positive gravity residual centre in the basin. Udensi, and Osazuwa (2004) estimated the average depth to basement to be $3.39 \mathrm{~km}$ with a maximum depth of $4.5 \mathrm{~km}$. Ojo (1990) investigated a major east-west magnetic low whose deep seated structures dominate the southern part of the basin with depths to basement varying between $4.0 \mathrm{~km}$ and $6.0 \mathrm{~km}$. Udensi (2001) identified the landward prolongation of St. Paul and Romanche fracture zones as lineaments passing through the northern and southern parts of Bida basin. In the spectral determination of depths to magnetic rocks in the Bida Basin, Udensi and Osazuwa (2004) were able to corroborate the interpretations of Ojo (1984) and Ojo and Ajakaiye (1989) that outlined the basin as being bounded by a system of linear faults. Olaniyan et al. (2012) used manual and automatic depth estimation methods to reveal depths ranging between $1 \mathrm{~km}$ and $1.50 \mathrm{~km}$ with some deep pockets around Mokwa, Kudu, Kotonkarfi, Auna, Akerre and Bida, ranging from $2.50 \mathrm{~km}$ to $3.75 \mathrm{~km}$ which could be reservoirs for hydrocarbon potentials. The depleting nature of the existing petroleum reserves and hence 
the associated products is a point of concern, as there is the possibility that the existing quantity may be exhausted in the nearest future.

There is, therefore, the need to explore for more reserves of hydrocarbons to complement and supplement the existing quantity. Consequently, the first step is a proper geophysical prospecting which would be aimed at ascertaining the presence of these minerals and then making appropriate recommendations. The Spectral depth analysis would help reveal the prospective areas for hydrocarbon accumulation.

Geology of the Study Area: The Bida basin is one of the seven inland basins of Nigeria containing sediment-fills of Cretaceous to Tertiary ages. The others are Niger Delta, Anambra, Benue Trough, Chad, Sokoto and the Dahomey (Benin) Embayment (Obaje, 2009). Figure 1 is the geological map of Nigeria showing the various geologic formations of Nigeria while Figure 2 is the geology and location map of the Bida basin and its environs.

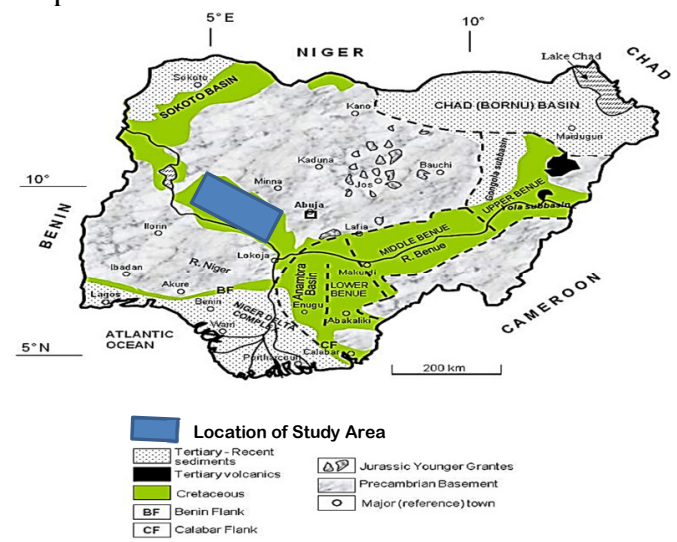

Fig 1: Geological map of Nigeria showing the major geological components (After Obaje, 2009).

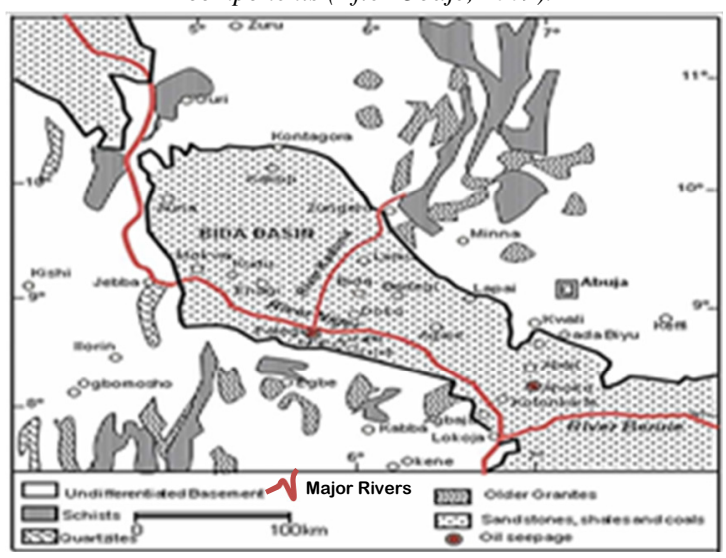

Fig 2: Geology and Location Map of Bida Basin and its Surroundings (Obaje, 2009)
The basin consists of the Bida and Lokoja formations which were produced during the Campanian, the Sakpe, Enagi, Batati, Patti and Agbaja formations which were created during the Maastrichtian. The Bida Formation is divided into the Doko Member and the Jima Member with the Doko Member located $16 \mathrm{~km}$ south of Bida and having a basal unit that consists of $80 \mathrm{~m}$ massive and flat bedded arkoses and coarse to medium sandstone with breccia horizons (Olaniyan et al., 2012). The sandstones of the Jima Member, according to Adeleye (1989), are dominantly quartzose, non-arkosic and brownish. Thin intercalations of poorly sort, hard, whitish, argillaceous sandstones are locally present in the lower parts of the Jima subfacies.

The Lithologic units in Lokoja Formation range from conglomerates, coarse to fine grained sandstones, siltstones and claystones in the Lokoja area (Akande et al., 2005). Subangular to subrounded cobbles, pebbles and granule sized quartz grains in the units are frequently distributed in a clay matrix. The Sakpe Formation comprises mainly oolitic and pisolitic ironstones with sandy claystones locally, at the base, followed by dominantly oolitic ironstone which exhibits rapid facies changes across the basin at the top (Adeleye, 1973). The Enagi Formation as described by Obaje (2009), on the other hand, consists mainly of siltstones and correlates with the Patti Formation in the Lokoja sub-Basin. Other subsidiary lithologies include sandstone-siltstone with some claystones. Fossil leaf impressions and rootlets have been found within the formation. The formation ranges in thickness between $30 \mathrm{~m}$ and $60 \mathrm{~m}$. Mineral assemblage consists mainly of quartz, feldspars and clay.

The Batati formation constitutes the uppermost units in the sedimentary sequence of the Bida Basin. It consists, according to Obaje et al. (2013), of argillaceous, oolitic and goethitic ironstones with ferruginous claystone and siltstone intercalations and shaly beds which occur in minor proportions some of which have yielded near shore shallow marine to fresh water fauna. The outcrops of the Patti Formation occur between Koton-Karfi and Abaji. This formation consists of sandstones, siltstones, claystones and shales interbedded with bioturbated ironstones with the argillaceous units predominating in the central parts of the basin. The Agbaja Formation forms a persistent cap for the Campanian Maastrichtian sediments in the Southern Bida Basin as a lateral equivalent of the Batati Formation on the northern side of the basin. It consists of sandstones and claystones interbedded with oolitic, 
concretionary and massive ironstone beds in this region.

\section{MATERIALS AND METHODS}

Data Acquisition: The 2009 IGRF corrected total magnetic field intensity data was acquired from the Nigeria Geological Survey Agency through the Ibrahim Badamasi Babangida University, Lapai Hydrocarbon Research Project which granted a third party access for the use of the data, while Oasis montaj 9.1 Software was used for the analysis and the Spectral Depth Analysis Method to determine the depth to basement rocks.

Spectral Depth Analysis Method: The spectral depths are usually computed from measurements made on the widths and slopes of individual anomalies of the aeromagnetic profiles. The method is based on the principle that a magnetic field measured at the surface can be considered to be the integral of magnetic signatures from all depths. This statistical approach has been found to yield good estimates of mean depth to basement underlying a sedimentary basin (Udensi, 2001). Spector and Grant (1970) developed the depth determination method which matches two dimensional power spectral calculated from gridded total magnetic intensity field data with corresponding energy spectral obtained from a theoretical model. A depth solution is calculated for the power spectrum derived from each grid sub-set and is located at the centre of the window.

For the purpose of analyzing aeromagnetic data, the ground is assumed to consist of a number of independent ensembles of rectangular, vertical sided parallelepiped with each ensemble characterized by a joint frequency distribution for the depth (h), length (b) and depth extent (t). In studying the characteristics of the residual magnetic field using statistical spectral methods, the data was transformed from the space to frequency domain and then the frequency characteristics analyzed.

The Fourier integral transform of a function that varies continuously along a profile of observation, such as magnetic field intensity, transforms the function from the space to the frequency domain, and is expressed, according to Sadek et al. (1984) as:

$\Delta \bar{T}\left(f_{y}\right)=\int_{-\infty}^{+\infty} \Delta T(y) \cdot e^{-2 \pi f_{y}} y d y$

where $\Delta \bar{T}\left(f_{y}\right)$ is the Fourier Transform of $\Delta T(y)$ $f_{y}=$ spatial frequency in the direction of the y-axis (cycles/unit length), $\Delta T(y)=$ potential-field intensity along $y$-axis, and $y=$ linear distance along the profile.
Sadek et al. (1984) further relates the energy density function $\mathrm{E}\left(f_{y}\right)$ and the Fourier transform by the relation:

$E\left(f_{y}\right)=\Delta \bar{T}\left(f_{y}\right) \cdot \Delta \bar{T}^{*}\left(f_{y}\right)$

Where $\Delta \bar{T}^{*}\left(f_{y}\right)$ is the complex conjugate of the Fourier Transform.

For depth estimates involving magnetic field data, eqn (2) is usually expressed according to Spector and Grant (1970) as:

$E(u, v)=\exp (-4 \pi h r)$

$\exp (-4 \pi h r)$ term is the dominant factor in the power spectrum. If we replace $h$ with $z$ and $r$ with $f$ due to the transformation from space to frequency domain, then

$\log E(f)=-4 \pi z f$

Where $z$ is the required anomalous depth; and $f$ the frequency.

The natural logarithmic values of $\mathrm{E}\left(f_{y}\right)$ are then plotted against frequency to produce a logarithmic energy spectrum or spectral energy-decay curve. To identify the characteristic depth of the magnetic basement, the steepest straight line segment which corresponds to the deepest segment of the power spectrum caused by consistent basement magnetic contrasts are identified for each window and used to generate the slope, so that the average depth determined when the slope is measured on a plot of $\ln \mathrm{E}\left(f_{y}\right)$ vs. $f$, is:

$\bar{h}=-\frac{\text { slope }}{4 \pi}$

or

$\bar{h}=-\frac{\text { slope }}{2}$

on a plot of amplitude spectrum $\ln A(f, \theta)$ vs $f$.

If two or more source ensembles are present, then the plot will show a corresponding number of linear intervals and the depths can be determined by measuring the slope of each interval separately.

\section{RESULTS AND DISCUSSION}

Spectral Depth Analysis was applied to the total magnetic field intensity data covering parts of Bida Basin to determine the depth to basement rocks as well as the basement morphology. The data was then divided into sixteen (16) overlapping spectral windows or ensembles (Figure 3) and Fast Fourier Transform (FFT) then performed on each of the windows to decompose the anomalies into their 
energy and frequency components after which the radial power spectrum was then calculated for each of the grid points. The locations of the centres of the ensembles are indicated on the map (Figure 3) from 1 to 16 and also shown on Table 1 with the latitudes, longitudes and evaluated depths to first and second magnetic layers. Thereafter, a plot of log of energy spectrum versus frequency in cycles per $\mathrm{km}$ was carried out using MatLab Plotter and straight lines were then manually fit to the energy spectrum curve, both in the higher and lower portions of the graphs to reveal two depth source models: $\mathrm{h}_{1}$ and $\mathrm{h}_{2}$ for shallow and deeper magnetic sources respectively. One of the graphs of the energy spectral vs frequency generated for the blocks is shown in Figure 4.

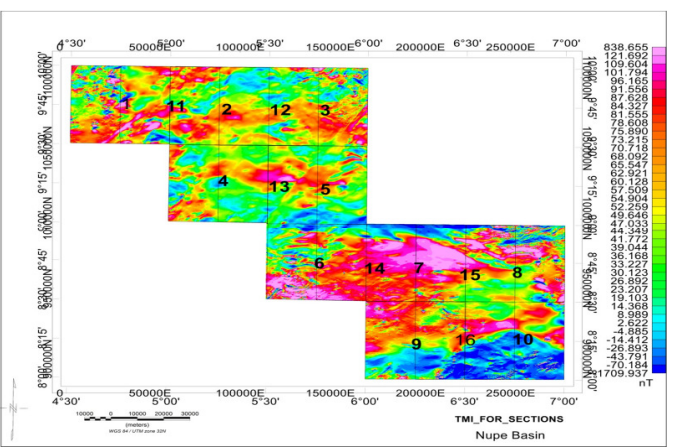

Fig 3: Spectral windows showing the centres of the ensembles

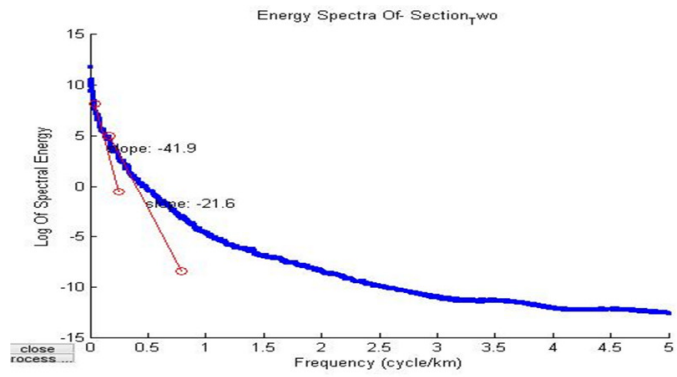

Fig 4: Graphs of Energy spectral vs frequency for Fashe block (Section 2).

The application of equation (5) in depth evaluation yielded depths to shallow magnetic sources $\left(h_{1}\right)$ ranging from $0.254 \mathrm{~km}$ on spectral block Block 9, which is the Kirri magnetic block to $1.719 \mathrm{~km}$ on the Fashe Block with an average depth value of about $0.968 \mathrm{~km}$. The depth to the deeper magnetic sources, $\mathrm{h}_{2}$, on the other hand, varies between $1.830 \mathrm{~km}$ in section 10 on the Kotonkarfi block and $4.615 \mathrm{~km}$ on section 15 which lies on the Baro/Gulu interface, with an average depth value of about $3.063 \mathrm{~km}$. The shallower magnetic sources could be attributed to the presence of near surface magnetic sources which could be ironstones or ferruginous sandstones or a combination of these magnetic sources that intruded into the sedimentary section close to the surface. There is also the likelihood of the influence of the adjoining magnetic basement around the study area. The deeper magnetic anomalies on the other hand could be attributed to the presence of intrusions of the magnetic basement into the basin at much deeper depths, lateral discontinuities in the basement and other features differing in magnetic susceptibilities such as dykes, faults, fractures, horsts and grabens within the study area.

Based on this result, the Kainji (1), Fashe(2), Mokwa(4), Egbako(5), Baro(7), Patigi/Baro(14) and Baro/Gulu(15) spectral blocks with sedimentary thickness values above $3.0 \mathrm{~km}$ show the greatest potential for hydrocarbon exploration. Figure 5 represents the extrapolated depths to deeper basement sources contour map for the location points at the middle of the ensembles. Figure 6 is the contour map of the extrapolated depths to shallow basement sources for the location points at the middle of the ensembles. Surfer 10 Software was used for the contouring at a contour interval of $100 \mathrm{~m}$ for deeper sources and $30 \mathrm{~m}$ for shallow sources so as to provide a clearer pictorial visualization of the prospective areas. The graphs show succinctly, areas with deep, moderate and shallow depths to magnetic sources as shown on the legend beside the graphs.

These results are in close agreement with the depths to basement in the region as reported by Ojo (1990), who put the depths at between $4 \mathrm{~km}$ and $6 \mathrm{~km}$; Udensi and Osazuwa (2004) who reported an average of $3.39 \mathrm{~km}$ with a maximum of $4.50 \mathrm{~km}$; Olaiyan et al. (2012) who obtained values between $2.50 \mathrm{~km}$ and $3.75 \mathrm{~km}$; Ofor et al. (2014) who had a range from $1.50 \mathrm{~km}$ to $4.70 \mathrm{~km}$, Ojo and Ajakaiye (1989) whose depth values varied from $1.00 \mathrm{~km}$ to $2.00 \mathrm{~km}$ and $\mathrm{Obi}$ et al. (2015) who delineated depths from $0.2 \mathrm{~km}$ to $4.2 \mathrm{~km}$.

Conclusion: The aeromagnetic data interpretation using Spectral Depth Analysis method has successfully delineated the depths to magnetic sources within the Bida basin, Nigeria. The areas corresponding to shallow depths and fault lines which have been identified within the study area can be considered for geotechnical and hydrogeological studies respectively. On the other hand, locations with high potentials for hydrocarbon prospects, based on the deeper depths to magnetic sources, have been revealed to include the Fashe, Mokwa, Baro, Egbako and Kotonkarfi magnetic sheets. 
Table 1: Table of spectral depth for the 16 ensembles of shallow and deeper magnetic sources

\begin{tabular}{|c|c|c|c|c|c|c|c|}
\hline 气̊. & 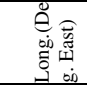 & 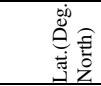 & 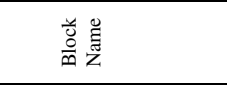 & 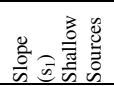 & 芯芯芯总 & $\begin{array}{l}\text { Depth to Shallow Sources } \\
h_{1}=\frac{s_{1}}{4 \pi}(\mathrm{km})\end{array}$ & $\begin{array}{l}\text { Depth to Deeper Sources } \\
h_{2}=\frac{s_{2}}{4 \pi}(\mathrm{km})\end{array}$ \\
\hline 1 & 4.75 & 9.75 & Kainji & 11.30 & 42.80 & 0.899225428 & 3.4059157822 \\
\hline 2 & 5.25 & 9.75 & Fashe & 21.60 & 41.90 & 1.718873385 & 3.3342960578 \\
\hline 3 & 5.75 & 9.75 & Akere & 9.25 & 36.00 & 0.736091612 & 2.8647889757 \\
\hline 4 & 5.25 & 9.25 & Mokwa & 19.00 & 46.30 & 1.511971959 & 3.6844369326 \\
\hline 5 & 5.75 & 9.25 & Egbako & 12.70 & 40.50 & 1.010633889 & 3.2228875976 \\
\hline 6 & 5.75 & 8.75 & Patigi & 11.60 & 34.00 & 0.92309867 & 2.7056340326 \\
\hline 7 & 6.25 & 8.75 & Baro & 14.00 & 47.00 & 1.114084602 & 3.7401411627 \\
\hline 8 & 6.75 & 8.75 & Gulu & 7.71 & 37.50 & 0.613542306 & 2.9841551830 \\
\hline 9 & 6.25 & 8.25 & Kirri & 3.19 & 30.90 & 0.253852134 & 2.4589438708 \\
\hline 10 & 6.75 & 8.25 & Kotonkarfi & 13.50 & 23.00 & 1.074295866 & 1.8302818456 \\
\hline 11 & 5.00 & 9.75 & Kainji/Fashe interface & 11.00 & 25.40 & 0.875352187 & 2.0212677773 \\
\hline 12 & 5.50 & 9.75 & Fashe/Akere interface & 11.00 & 36.00 & 0.875352187 & 2.8647889757 \\
\hline 13 & 5.50 & 9.25 & Mokwa/Egbako interface & 15.00 & 32.80 & 1.193662073 & 2.6101410667 \\
\hline 14 & 6.00 & 8.75 & Patigi/Baro interface & 13.90 & 49.00 & 1.106126854 & 3.8992961058 \\
\hline 15 & 6.50 & 8.75 & Baro/Gulu interface & 12.60 & 58.00 & 1.002676141 & 4.6154933497 \\
\hline 16 & 6.50 & 8.25 & Kiri/Kotonkarfi interface & 5.31 & 34.80 & 0.422556374 & 2.7692960098 \\
\hline
\end{tabular}

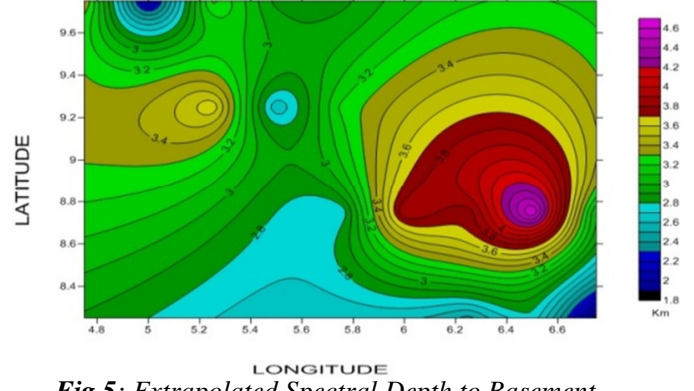

Fig 5: Extrapolated Spectral Depth to Basement Contour map using Surfer 10 software at Contour interval of $1000 \mathrm{~m}$.

\section{REFERENCES}

Adeleye, D. R. (1973). Origin of ironstones, an example from the middle Niger Basin, Nigeria. Journal of Sedimentary Petrology 43, 709-727.

Adeleye, D. R. (1989). The Geology of the middle Niger basin. In: Kogbe, C.A. (Ed.), Geology of Nigeria, second ed. Elizabethan Publishing Co., Lagos, 335-338.

Akande, S.O., Ojo, O.J., Erdtmann, B.D. and Hetenyi, M. (2005). Paleoenvironments, organic petrology and Rock-Eval studies on source rock facies of the Lower Maastrichtian Patti Formation, southern Bida Basin, Nigeria. Journal of African Earth Sciences, 41, 394-406.

Megwara, J. U. and Udensi, E. E. (2014). Structural Analysis Using Aeromagnetic Data: Case Study of Parts of Southern Bida Basin, Nigeria and the Surrounding Basement Rocks. Earth Science Research, 3 (2), 27- 42

Obaje N. G. (2009). Geology and Mineral Resources of Nigeria, Lecture Notes in Earth Sciences. Springer Dordrecht Heidelberg, London New York. 221p.

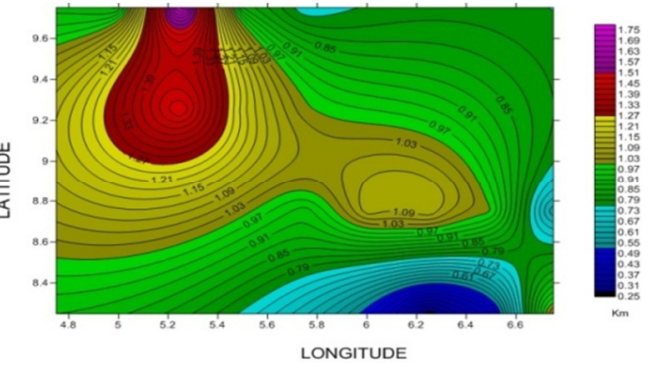

Fig 6: Extrapolated Contour map showing Spectral Depth to Shallow Sources in the Study Area, using Surfer 10 software at Contour interval of $30 \mathrm{~m}$

Obaje, N. G., Balogu,D. O., Idris-Nda, A., Goro, I. A., Ibrahim, S. I., Musa, M. K. Dantata, S. H., Yusuf I., Mamud-Dadi, N. and Kolo I. A (2013). Preliminary Integrated Hydrocarbon Prospectivity Evaluation of the Bida Basin in North Central Nigeria. Petroleum Technology Development Journal, 3 (2), 36-65.

Ofor, N. P., Adam, K. D. and Udensi, E. E. (2014). Spectral Analysis of the Residual Magnetic Anomalies Over Pategi and Egbako Area of the Middle Niger Basin. Nigeria. Journal of Natural Sciences Research, 4(9), 44-50.

Ojo, S. B. (1984). Middle Niger Basin revisited magnetic constraints on gravity interpretations. A paper presented at the 20th Nigeria Mining and Geosciences Society Conference, Nsukka, Nigeria, Conference proceedings, 52-53.

Ojo, S. B. (1990). Origin of a major magnetic anomaly in the Middle Niger Basin, Nigeria. Tectonophysics, $\quad 85, \quad 153-162$. dx.doi.org/10.1016/0040-1951(90)90410-A

Ojo, S. B. and Ajakaiye, D. E. (1989). Preliminary interpretation of gravity measurements in the middle Niger Basin area, Nigeria. In: Kogbe, C.A. 
(Ed.), Geology of Nigeria, second ed. Elizabethan Publishing Co., Lagos, 347-358p.

Olaniyan, O., Abbah, U., Nwonye, N., Alichi, A. and Udensi, E.E. (2012). Interpretation of Total Magnetic Intensity Field over Bida Basin. Nigerian Geological Survey Agency. Occasional Paper No. 15. 98p.

Sadek, H. S., Rashad, S. M., and Blank, H. R. (1984). Spectral analysis of aeromagnetic profiles for depth estimation principles, software, and practical application. Open-File Report 84, U.S. Geological Survey Mission, Saudi Arabia.
Spector, A., and Grant, F.S. (1970), Statistical Models for interpreting aeromagnetic data. Geophysics Vol. (35), 293-302.

Udensi, E. E. and Osazuwa, I. B. (2004). Spectra determination of depths to magnetic rocks under the Nupe basin, Nigeria. Nigeria Association of Petroleum Explorationists (NAPE) Bulletin 17, 22-27.

Udensi, E.E. (2001). Interpretation of the total magnetic field over the Nupe basin in West Central Nigeria using aeromagnetic data. Ph.D thesis Dept of Physics ABU, Zaria, Nigeria. 